\title{
ダビガトラン服用患者の抜歯に関する検討
}

\author{
吉川博 政 ${ }^{1,2)}$ ·吉田将律 ${ }^{1,2)} \cdot$ 木村祥一郎 ${ }^{1,2)}$ \\ 永井清志 ${ }^{2,3)}$. 福元 俊輔 2,3 )

\section{Clinical study of tooth extraction in patients receiving dabigatran} \\ YOSHIKAWA Hiromasa $^{1,2)} \cdot$ YOSHIDA Masanori $^{1,2)} \cdot$ KIMURA Syouichiro $^{1,2)}$ \\ NAGAI Kiyoshi ${ }^{2,3)} \cdot$ FUKUMOTO Shunsuke $^{2,3)}$
}

\begin{abstract}
Dabigatran is a novel oral anticoagulant (NOAC) and a direct thrombin inhibitor. There is limited information available about tooth extraction in patients receiving dabigatran because of its status as an NOAC. We studied the safety of tooth extraction in 19 patients who continued to receive dabigatran. The average age was 72.0 years, and a total of 55 teeth were extracted. The mean active partial thromboplastin time (APTT) was 45.4 seconds. In 1 patient the APTT was prolonged to more than 70 seconds. All patients underwent tooth extraction 6 to 8 hours after taking dabigatran in consideration of the half-life in blood. Postoperative bleeding occurred in the patient in whom the APTT was prolonged to more than 70 seconds. Dabigatran had to be temporarily withdrawn in 1 patient and resumed after the cessation of bleeding. Measurement of APTT before extraction is essential. We consider tooth extraction feasible without the cessation of dabigatran if the patient's APTT is controlled to less than 2 times the reference value. If the APTT is prolonged to longer than 60 seconds, tooth extraction must be carefully performed.
\end{abstract}

Key words: dabigatoran (ダビガトラン), tooth extraction (抜㐘), activated partial thromboplastin time (APTT)

\section{緒言}

近年，経口抗凝固薬として血栓症の治療と予防に広く用 いられてきたワルファリンに代わり，血液凝固因子のトロ ンビンやX a 因子を直接阻害する新しい経口抗凝固薬が開 発され使用されるようになった。このなかでダビガトラン は, 非弁膜症性心房細動による脳塞栓症や全身性塞栓症の

1) 国立病院機構九州医療センター柬科口腔外科 (主任：吉川博政部長)

2) 国立病院機構九州医療センター臨床研究センター (主任：岡田 靖センター長)

3) 国立病院機構福岡東医療センター柬科口腔外科 (主任：福元俊輔医長)

${ }^{1)}$ Department of Dentistry, Oral and Maxillofacial Surgery, National Hospital Organization Kyushu Medical Center (Chief: Dr. YOSHIKAWA Hiromasa)

${ }^{2)}$ Clinical Research Institute, National Hospital Organization Kyushu Medical Center (Chief: Dr. OKADA Yasushi)

${ }^{3)}$ Department of Dentistry, Oral and Maxillofacial Surgery, National Hospital Organization Fukuoka Higashi Medical Center (Chief: Dr. FUKUMOTO Shunsuke)

受付日：2015年 8 月 19 日

採択日：2016 年 3 月 29 日
発症予防薬として，2011年 3 月に承認された最初の新規 経口抗凝固薬である。ワルファリンがビタミン $\mathrm{K}$ 依存性の 凝固蛋白, すなわち第 II, VII, IX, X 因子を減少させるこ とで抗凝固作用を示すのに対し，ダビガトランはフィブリ ン生成に関与するトロンビンを直接阻害する薬剤である。 この薬はワルファリンと異なり, 薬物や食品との相互作用 が少なく血中半減期が短いが, 腎排泄型であるため腎機能

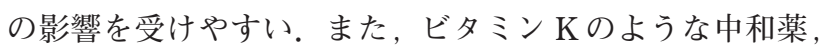
PT-INRのような抗凝固能の程度を示す明確な指標がない. ダビガトラン服用患者の抜柬を行う際, 抗血栓療法患者の 抜蒾に関するガイドライン 2015 年改訂版 ${ }^{1)}$, 心房細動治 療 (薬物) ガイドライン 2013 年改訂版 ${ }^{2}$ ) では, ワルファ リンに準じて服用継続下での抜歯が勧められている。しか し, 現状では今後の観察研究を含めたデータの蓄積が必要 な段階で, これまで本邦における抜㐘時の服用中止, 継続 に関する報告はない。今回，ダビガトラン服用患者の抜㐘 症例を後ろ向きに調査し, ダビガトラン服用継続下での抜 㐘の可能性について検討した。 


\section{研究対象・方法}

対象は, 2011 年 6 月から 2015 年 3 月までに国立病院機 構九州医療センター, 福岡東医療センター㐘科口腔外科を 受診したダビガトラン服用患者のうち抜㐘を行った 19 例 (男性 15 例, 女性 4 例, 平均年齢 72.0 歳) 55 歯で, 抜柬回 数は 25 回であった。抜柬に至った原因疾患は，う蝕 24 㐘， 根尖性柬周炎 17 柬，辺縁性柬周炎 13 柬，下顎智柬周囲炎 1 㐘であった。

全症例とも，入院下にダビガトラン (プラザキサ $\left.{ }^{\circledR}\right)$ 服 用継続下に抜菌を行った。抜柬は，血漿中ダビガトラン濃 度と APTT の推移 (内服後 6 時間経過すると血漿中ダビガ トラン濃度が最高濃度から $50 \%$ 以下に低下し, APTT 比が 正常範囲に近づく）を参考に $\left.{ }^{3}\right)$ ，抜柬後出血のリスクを軽 減できると考えられる内服後 6 時間以上を待ってから行っ ていた。また，止血に問題なければ 2 回目を服用させてい た。抜柬は 8 万倍エピネフリン含有 $2 \%$ ネシロカインを用 い行っていた。抜㐘窩は柬肉縁部軟組織の不良肉芽を十分 掻爬し，血餅が抜㐘窩から出ないようゼラチン製剤を填入 後，単純抜柬などでは減張切開は行わずに $3-0$ 絹糸で柬 肉縁を縫合圧迫止血を行い, 止血シーネは使用せずガーゼ のみで圧迫していた。術後はセフェム系抗菌薬を 3 日間経 口投与していた。抜柬後の経過観察期間は抜糸時までの 1 週間から 10 日間であった。

患者背景として，心房細動患者に打ける脳梗塞発症リス ク評価スコアとして提唱されている CHADS 2 スコア $(0$ 〜 6 点) ${ }^{2}$ ) (Congestive heart failure うっ血性心不全, Hypertension 高血圧, Age $\geqq 75 y 75$ 歳以上, Diabetes mellitus 糖 尿病, Stroke 脳卒中) , ダビガトラン服用量, ワルファリン 服用歴， APTTを調査した。ダビガトランは当初凝固能の モニタリングが不要であるとされてきたが，発売後国内外 を問わず超高齢者，腎機能低下者で出血性合併症の増加が 報告され，2011 年 8 月には厚生労働省から安全性速報 ${ }^{4)}$ が出されるに至り，投与前の腎機能の確認や血液凝固に関 する検査が求められるようになった，凝固能の測定につい ては，APTTがダビガトランの血中濃度上昇と相関してい ることが報告されている ${ }^{3,5)}$ 。しかしながら，2012 年まで は APTT 測定の意義が明確になっておらず，測定は行って いなかった。一方, 2012 年 8 月からは, 抜柬前 1 週間以 内, 2013 年 8 月以降は抜菊当日（服用 3 時間後）にAPTT を測定するようになっていた。 2014 年 1 月からの 8 例に ついては, APTTがダビガトラン服用後の血中濃度と相関 し，抜㐘のタイミングを決めるうえで有用か否かを検討す るために，抜柬当日の服用 3 時間後 (血中濃度ピーク時)， 抜歯直前 (服用 6 7 時間後)，抜㐘翌日の服用前（ダビガ トラン血中濃度が半減したと考えられる時期）の APTTを 測定した。
また，抜歯後出血および血栓症・出血性合併症の有無に ついて調査した．なお，出血の判定には，新美らの基準 ${ }^{6)}$ を用いた。

本研究は, 九州医療センター倫理委員会の承認を受け, 国立病院機構 EBM 推進のための大規模研究「観血的医療 処置時の抗血栓薬の適切な管理に関する研究」(代表研究 者：矢坂正弘 九州医療センター脳血管内科）の一環として 行われた。

\section{結果}

\section{1．患者背景と APTT 測定（表 1, 図 1)}

対象症例の平均年歯令は 72.0 歳であり, 最高年齢は 83 歳 であった。全例, 非弁膜症性心房細動のためダビガトラン の投与を受けていた。 19 例中 6 例で脳梗塞の既往があり， CHADS 2 スコアは 1 点が 4 例, 2 点が 7 例, 3 点が 4 例で 脳卒中のリスクが非常に高くなる 4 点が 4 例であった。ダ ビガトランの服用量は 19 例中 16 例で 1 日 $220 \mathrm{mg}$ であり， $300 \mathrm{mg}$ 服用は 3 例のみであった。なお， 12 例にワルファ リン服用の既往があった。 APTTの平均值は 45.4 秒で， 70 秒以上に延長した症例が 1 例みられた。APTTの時間的経 過を調查できた 8 例では, APTTの時間的変化に個人差が あり，血中濃度ピーク時に比べ抜柬時や翌日服用前に上昇 する症例が認められた。ピーク時と翌日服用前の差は 0.8 秒から 17.4 秒であった。

\section{2.ダビガトラン服用継続下での抜歯}

全例でダビガトラン服用継続下に抜柬を行った。1回あ たりの抜歯数は 1 歯が 14 回, 2 歯が 4 回, 3 歯が 3 回, 4 歯が 1 回，5 㐘以上の抜㐘は 3 回で，骨膜剥離と骨開削を 要する難抜柬となった 2 柬, 下顎埋伏智柬抜柬となった 1 歯を含んでいた。25回の抜㐘を行い，症例 19 で抜柬後出 血が 1 回認められた。抜㐘後の経過観察中に抜㐘部位から の再出血, 血栓症・出血性合併症の発症は認めなかった。

\section{3. 抜歯後出血症例}

症例は 78 歳男性, 脳梗塞の既往があり 2011 年 6 月から ダビガトランを服用していた。服用量は当初より $220 \mathrm{mg} /$ 日 であり腎機能 $\mathrm{CCr}$ は $45.2 \mathrm{~mL} / \mathrm{min}$ であった。入院時 APTT が 71.8 秒と過剩延長を認めたが，抜歯直前の測定では 60.5 秒に低下していたため 4 㐘の抜㐘を行った（写真 $\mathbf{1}$ ). 876 部は不良肉芽が多く肉芽掻爬時に出血を認めたが, ゼラチン製剤を填入後，創部は 3-0 絹糸で縫合，17 時に 終了しガーゼによる創部の圧迫を行った。しかしながら， 微量の出血が続いたため止血シーネを装着し, 止血可能と 判断したため 21 時にダビガトランの 2 回目の服用を行っ た。しかし，翌朝に止血シーネを除去したところ，抜柬部 
表 1 対象症例の一覧

症例の年齢, 脳梗塞の既往, CHADS 2 スコア, APTT, ダビガトラン服用量, ワルファリン服用歴, 抜㐘部位・蒾数, 抜蒾後出血の有無について調査した.

\begin{tabular}{|c|c|c|c|c|c|c|c|c|c|c|c|}
\hline $\begin{array}{l}\text { 症 } \\
\text { 例 }\end{array}$ & $\begin{array}{l}\text { 年 } \\
\text { 齢 }\end{array}$ & $\begin{array}{l}\text { 性 } \\
\text { 別 }\end{array}$ & 病 名 & $\begin{array}{l}\text { 脳梗塞 } \\
\text { 既往 }\end{array}$ & $\begin{array}{c}\text { CHADS } 2 \\
\text { スコア }\end{array}$ & $\begin{array}{l}\text { ダビガトラン } \\
1 \text { 日投薬量 } \\
(\mathrm{mg})\end{array}$ & $\begin{array}{l}\text { ワルファリン } \\
\text { 服用歴 }\end{array}$ & $\begin{array}{l}\text { APTT } \\
(\text { 秒 })\end{array}$ & 抜歯部位, 抜柬理由 & $\begin{array}{l}\text { 抜歯数 } \\
\text { (歯) }\end{array}$ & $\begin{array}{l}\text { 抜歯後 } \\
\text { 出血 }\end{array}$ \\
\hline 1 & 72 & M & 心房細動 & $(+)$ & 4 & 220 & $(+)$ & & 466 Per & 2 & $(-)$ \\
\hline 2 & 72 & M & 心房細動 & $(+)$ & 3 & 220 & $(-)$ & 45.3 & $\sqrt{8} \mathrm{C}$ & 1 & $(-)$ \\
\hline 3 & 61 & M & 心房細動 & $(-)$ & 1 & 300 & $(-)$ & & $\begin{array}{l}\lfloor 7 \text { C, } \sqrt{4} \text { C (骨削合), } \sqrt{6} \text { Per } \\
\lfloor 7 \text { C (骨削合), } \overline{76} \text { C }\end{array}$ & $\begin{array}{l}3 \\
3\end{array}$ & $\begin{array}{l}(-) \\
(-)\end{array}$ \\
\hline 4 & 83 & M & 心房細動 & $(-)$ & 3 & 220 & $(+)$ & & $\begin{array}{l}\sqrt{7} \quad \mathrm{C} \\
\qquad 8 \mathrm{C}, \overline{4} \text { Per }\end{array}$ & $\begin{array}{l}1 \\
2\end{array}$ & $\begin{array}{l}(-) \\
(-)\end{array}$ \\
\hline 5 & 46 & M & 心房細動 & $(-)$ & 1 & 220 & $(+)$ & 40.8 & $\sqrt{8}$ 水平埋伏歯 & 1 & $(-)$ \\
\hline 6 & 65 & $\mathrm{~F}$ & 心房細動 & $(+)$ & 2 & 300 & $(+)$ & 68.1 & $\overline{4} \mathrm{C}$ & 1 & $(-)$ \\
\hline 7 & 80 & $\mathrm{~F}$ & 心房細動 & $(-)$ & 4 & 220 & $(-)$ & 53.3 & $\sqrt{6}$ Per & 1 & $(-)$ \\
\hline 8 & 64 & M & 心房粗動 & $(-)$ & 2 & 220 & $(+)$ & 47.4 & $18 \quad \mathrm{C}$ & 1 & $(-)$ \\
\hline 9 & 70 & M & 心房細動 & $(-)$ & 1 & 220 & $(+)$ & 43.0 & $\lfloor 3 \quad \mathrm{P}, \overline{7} \mathrm{C}$ & 2 & $(-)$ \\
\hline 10 & 78 & M & 心房細動 & $(-)$ & 3 & 220 & $(+)$ & 50.8 & 6) C & 1 & $(-)$ \\
\hline 11 & 68 & M & 心房細動 & $(-)$ & 1 & 300 & $\begin{array}{l}(-) \\
(-)\end{array}$ & $\begin{array}{l}46.6 \\
43.5\end{array}$ & $\begin{array}{l}\underline{8} \mathrm{C}, \sqrt{678} \mathrm{P}, \overline{5} \text { Per } \\
\underline{4321 \mid 127} \mathrm{P}, \quad\lfloor 35 \mathrm{C}\end{array}$ & $\begin{array}{l}5 \\
9\end{array}$ & $\begin{array}{l}(-) \\
(-)\end{array}$ \\
\hline 12 & 80 & M & 心房細動 & $(-)$ & 2 & 220 & $(+)$ & 39.0 & $4 \quad \mathrm{C}$ & 1 & $(-)$ \\
\hline 13 & 71 & $\mathrm{~F}$ & 心房細動 & $(+)$ & 4 & 220 & $(+)$ & 34.0 & $\underline{63 \mathrm{C}} \mathrm{C} \overline{1 / 126} \mathrm{C}$ & 6 & $(-)$ \\
\hline 14 & 77 & M & 発作性心房細動 & $(-)$ & 2 & 220 & 不明 & 47.7 & $\underline{5}$ Per & 1 & $(-)$ \\
\hline 15 & 77 & M & 発作性心房細動 & $(-)$ & 2 & 220 & $(+)$ & $\begin{array}{l}45.0 \\
45.6\end{array}$ & $\begin{array}{l}77 \text { Per } \\
4 \mathrm{P}\end{array}$ & $\begin{array}{l}1 \\
1\end{array}$ & $\begin{array}{l}(-) \\
(-)\end{array}$ \\
\hline 16 & 72 & $\mathrm{~F}$ & 心房細動 & $(+)$ & 3 & 220 & 不明 & 47.8 & $7 \mathrm{P}$ & 1 & $(-)$ \\
\hline 17 & 76 & M & 心房細動 & $(-)$ & 2 & 220 & 不明 & 30.9 & $\lfloor 45$ Per & 2 & $(-)$ \\
\hline 18 & 78 & M & 心房細動 & $(-)$ & 2 & 220 & $(+)$ & $\begin{array}{l}53.3 \\
35.9\end{array}$ & $\begin{array}{l}765 \text { Per } \\
8 \text { Per }\end{array}$ & $\begin{array}{l}3 \\
1\end{array}$ & $\begin{array}{l}(-) \\
(-)\end{array}$ \\
\hline 19 & 78 & M & 心房細動 & $(+)$ & 4 & 220 & $(+)$ & $\begin{array}{l}71.8 \\
46.6\end{array}$ & $\begin{array}{l}6, \overline{876} \mathrm{C}, \text { Per } \\
\sqrt{6} \text { Per }\end{array}$ & $\begin{array}{l}4 \\
1\end{array}$ & $\begin{array}{l}(+) \\
(-)\end{array}$ \\
\hline
\end{tabular}

+ : 有り 一 : なし

APTT 基準範囲：九州医療センター $26.5 \sim 39.5$ 秒 福岡東医療センター 26.0 〜 35.0 秒
症例 $3,18,19$ は入院中 2 回に分けて抜柬を行った 症例 $4,11,15$ は入院日は異なり, 入院中の抜歯は 1 回
に不良血餅を認め, 辺縁から軽度の出血がみられたため， 抜柬窩不良血餅の除去，再掻爬，縫合を行い止血した。ま た, APTTが 63 秒と延長しており服用後にAPTTの過剩 延長による再出血が懸念されたため, 内科主治医と協議の 上, CHADS 2 スコア 4 とハイリスク群であったが, 抗凝
固状態は維持されていると推測し，午前の服用を中止し完 全な止血を確認後, 夕方から服用を再開した。なお, 再開 直前の APTT は 45.6 秒であった。翌日 APTTを再度測定 し 52.2 秒と過剩延長がないため, 残りの 1 柬を抜柬した が止血に問題はなかった。 


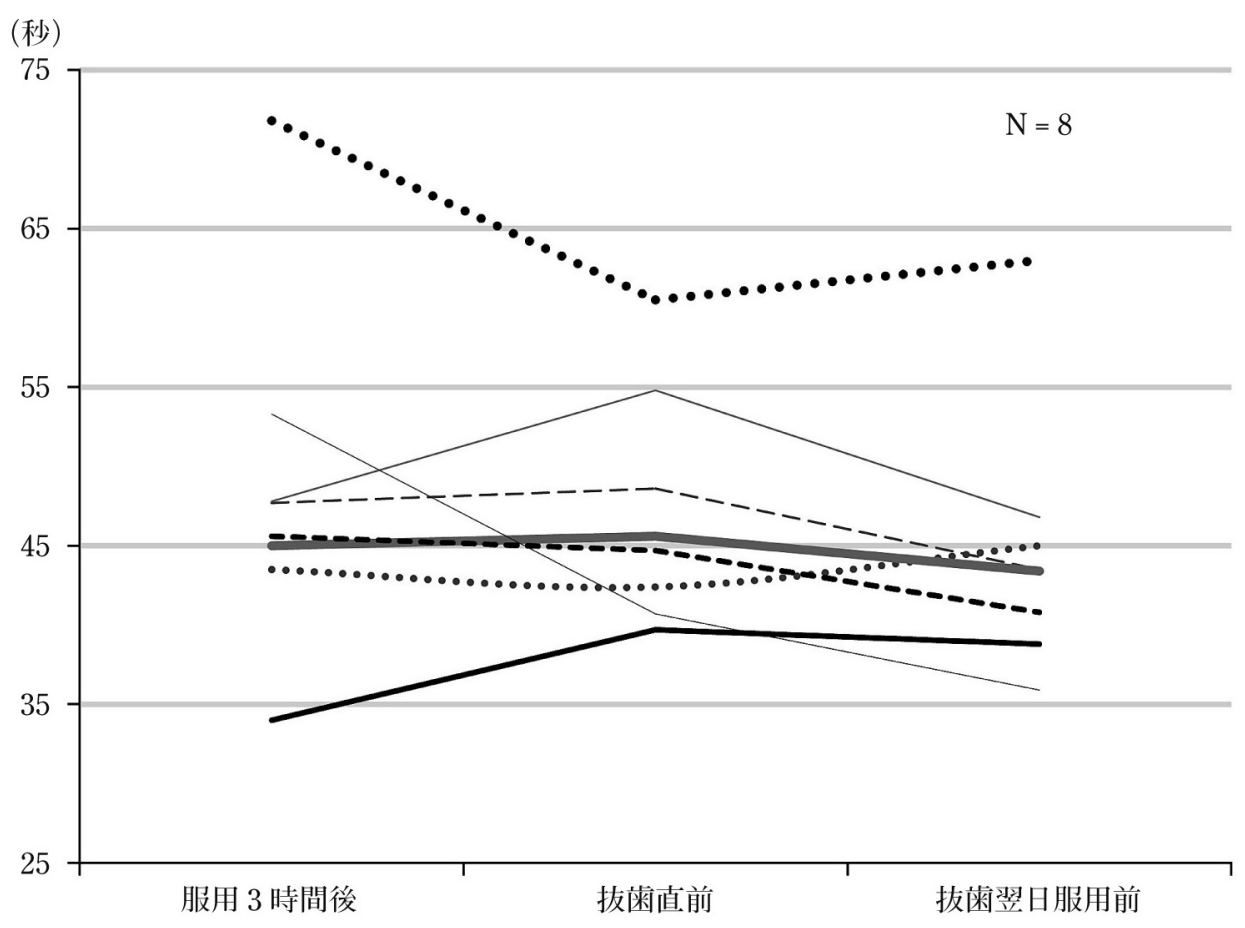

図 1 抜藏前後の APTT の変化

8 例について抜㐘当日服用 3 時間後（血中濃度ピーク時），抜㐘直前

(服用 $6 \sim 7$ 時間後)，抜柬翌日服用前の APTT を測定した.

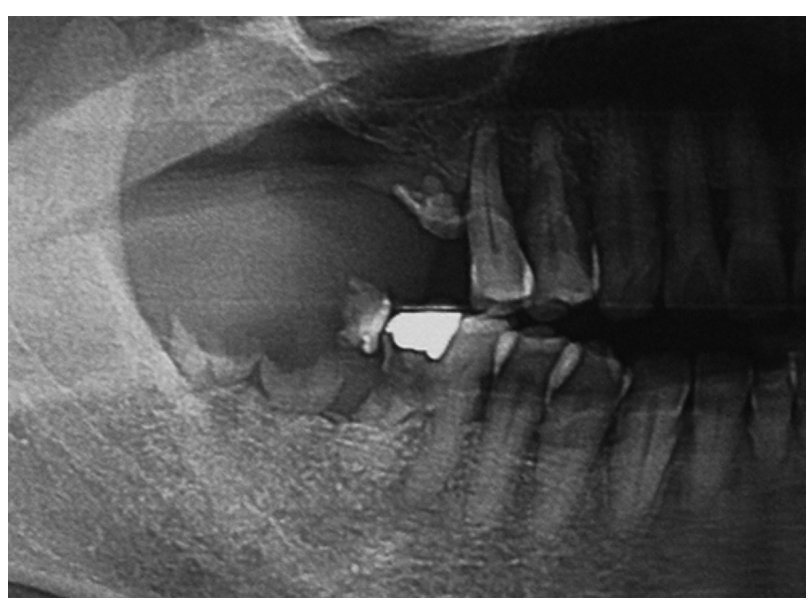

写真 1 抜㐘後出血症例のパノラマX $\mathrm{X}$ 線写真

$\overline{8-6} ， 6$ の抜柬を行い, 76 部から出血を認める.

\section{考察}

\section{1. 患者背景とダビガトラン投与量について}

全例とも非弁膜性心房細動のためダビガトランの投与を 受けていた．心原性脳塞栓症の原因の多くは心房細動で， その発症率は加齢とともに増大し, 2050 年に日本で心房 細動を有する人口は, 現在の 70 万人から 103 万人になる
と予想されている ${ }^{2)}$. 静脈血栓症の治療や予防に用いられ る抗凝固薬は, 従来よりビタミン $\mathrm{K}$ 拮抗薬のワルファリ ンが用いられてきたが ${ }^{2)}$, ワルファリンの問題点を解決す ベく開発された薬剤が経口直接トロンビン阻害薬や X a 因 子阻害薬である。経口直接トロンビン阻害薬であるダビガ トランは, 日本人を含む非弁膜症性心房細動患者を対象と した第 III相国際共同臨床試験（RE-LY 試験） 7 ）にて，ワル ファリンと比較して出血性合併症の危険性を高めることな く，有意に全身性塞栓症を予防することが示された。ワル ファリンと異なり, 直接トロンビン阻害作用のため選択性 が高く, 食品や薬物との相互作用が少ないため服用患者が 増加している。今回の症例のうち, 12 例はワルファリン からの服用薬変更の患者であった.

対象症例の平均年齢は 72.0 歳で 75 歳以上の症例も 9 例 あり, 最高年齢は 83 歳であった。心房細動の有病率は, 80 歳以上では人口の 9 〜 $14 \%$ を占める ${ }^{2)}$ と推測され, 今 後ダビガトランを含む新規経口抗凝固薬の服用患者が増加 すると思われる. CHADS 2 スコアは 1 点の症例が 4 例の みで, 脳梗塞の既往を有し再梗塞のリスクが高い 4 点が 3 例であった。投与量は, 厚生労働省の安全情報の基準に 基づき, 70 歳以上の患者では出血性合併症を考慮して, 全例 1 日 $220 \mathrm{mg}$ であった. 1 例のみ 46 歳で $220 \mathrm{mg}$ の投与 
例がみられたが, この症例は併用薬との関係で $220 \mathrm{mg}$ が 選択されていた。腎機能が $\mathrm{CCr} 30 \mathrm{~mL} / \mathrm{min}$ を下回る症例は なく, 投与量の決定に関しては年齢が大きな要因を占めて いたと推測される.

\section{2. ダビガトランの抗凝固指標について}

ワルファリンは効果に個体差があり，食事や薬剤の影響 を受けるため定期的な凝固検査が必要で, その指標として PT-INR が用いられる。ダビガトランによる出血リスクを正 確に評価できる指標は現在のところ確立されていない．服 用時の血液凝固機能を知る目安として APTTの測定が推奨 されており, APTTはダビガトランの血中濃度上昇と相関 していることが報告されている ${ }^{3,5}$ )。しかし, 測定值は腎 機能，年齢などによる個人差が大きく，同一患者でも測定 值は一定ではなく，施設によって基準值も異なるため $\left.{ }^{8}\right)$, ワルファリンの PT-INRのような効果判定の指標とはなら ない. 一方, 服用時の出血性合併症のリスクの指標として は用いられており，測定值が基準值の 2 倍あるいは 80 秒 を超えた場合は, 出血性合併症の危険性が高いとされてい る ${ }^{9)}$. 今回測定した症例でAPTT が基準值の 2 倍を超える 症例はなかった。しかし，71.8 秒と過剩延長を示した症例 が 1 例認められた。

ダビガトランの生物学的利用率は $6.5 \%$ ありり, 何らか の原因でその吸収率が変化するだけで効果が変動する可能 性が示唆されている ${ }^{9)}$ が詳細は不明である。今回我々は, 抜柬後出血のリスクを低下させるため，ダビガトランの血 中半減期を考慮し服用後 6 時間以上経過してから抜㐘を 行った. ダビガトランの血中濃度が APTT に反映されるか 否かについて，症例は少ないが抜柬当日服用 3 時間後，抜 歯直前 (服用 6 ～7 時間後)，抜㐘翌日服用前の APTT を測 定した。血中濃度ピーク時に比べ, 抜歯時の APTT が下降 することを予想したが，測定結果は症例によって異なり， 血中濃度ピーク時に比べ抜歯時や翌日の測定で上昇した症 例も認められ，抜柬時の APTT が血中濃度ピーク時に比べ 必ずしも低下するとは限らないという結果が得られた。

ダビガトランによりトロンビンの活性が抑制されると， 第XI因子，第VIII因子，第 V因子の活性化も抑制されるため 内因系凝固因子の異常を反映する APTT が延長すると考え られており, APTTの過剩延長を認めた症例で抜柬後出血 が認められたこともあり，APTTの測定は抜㐘後出血のリ スクを判断するうえで有用と思われる。ただし，どの程度 延長すると抜柬後出血の危険性が高まるかは症例が少ない ため，今後の症例の蓄積を待たなければならない．測定時 期については，抜㐘当日，可能であれば服用前を避け，血 中濃度を考慮し服用 $2 \sim 3$ 時間後から抜柬前が適切と考え ている。

\section{3.ダビガトラン服用継続下での抜歯について}

ワルファリンを抜歯時に中断した場合，約 $1 \%$ に重篤な 血栓塞栓症が発症することが知られており, 服用継続下で の抜歯が推奨されている ${ }^{1,2)}$. ダビガトランでも休薬に伴 う血栓塞栓症が認められており，その発症率はワルファリ ン休薬と同程度であることが報告されている ${ }^{10)}$. ダビガ トラン服用患者の抜㐘を行う際, 単純抜柬であればダビガ トランの中止は必要ないが 11 13), 多数菊では抜柬 24

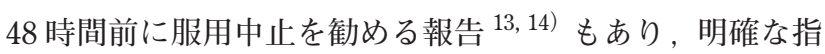
針は得られていない，我々は，休薬に伴う脳梗塞発症のリ スクを回避するため服用継続下に抜㐘を行った。2 5 回抜 歯を行ったが, APTTが 71.8 秒と過剩延長を認めた 1 例に 抜柬後出血を認めた。抜柬前にAPTT を測定し，過剩延長 がなければ，抜柬数に関係なく今回の方法のように投与時 の最高血中濃度時を避け，服用 6 ～8 時間後に行うことで ダビガトラン服用継続下での抜柬は可能と思われる. 服用 継続下で抜柬後出血が起こった場合, 圧迫で止血できない ときは抜㐘窩を再度明示し出血部を確認後, ゼラチン製剂 を填入し縫合, 必要に応じて止血シーネなどを用いて圧迫 止血を試みる。それでも止血できない場合は，ダビガトラ ンの服用 1 回中止を検討せざる得ない. ダビガトランは半 減期が短いため, 1 回の服用中止で止血は可能と思われる が，中止することで塞栓症の発症リスクが高まるため，抜 歯前に，止血困難な場合のダビガトラン中止の可能性につ いて医科主治医と協議しておくことや，塞栓症の発症リス クを記載した抜藏同意書を作成し患者の同意を得たうえで 実施することが望ましい.

なお, APTTが過剰に延長している場合には, 出血性合 併症の危険性もあり，抜㐘は行わず医科主治医を受診させ ることが必要である。過剩延長の程度によるが, 主治医と の協議にて抜㐘可能と判断した場合は，抜歯当日朝 1 回目 の服用を中止し，止血を確認後夕方の 2 回目から再開する か，あるいは服用継続下に抜㐘を行い，出血が続くようで あれば，当日夕方の 2 回目の服用を中止し，止血が得られ れば翌朝から再開することで止血管理は可能と思われる. 1 回服用を中止して抜㐘する方法, 出血があれば 1 回服用 を中止する方法のかどちらが適切であるか, また 1 回の中 止が血栓塞栓症発症にどの程度の影響を及ぼすかについて は今後の症例の蓄積を待たなければならない.

\section{結語}

ダビガトラン服用継続下に 19 例（55 㐘）で抜柬を行っ た. 抜歯前の APTT が過剩延長した 1 例で抜歯後出血を認 めたが，その他の症例は問題なかった。 APTTが基準值の 2 倍を超えなければダビガトランは中止せず抜㐘は可能と 思われるが，今回の結果から 60 秒を超える場合は注意が 
必要と考えている.

謝辞

稿を終えるにあたり，内科的御指導をいただきました当院 脳血管内科科長・臨床研究推進部長 矢坂正弘先生に深謝いた します。

本論文に関して，開示すべき利益相反状態はない

\section{引用文 献}

1) 日本有病者柬科医療学会, 日本口腔外科学会, 他編; 科学的根拠に基づく抗血栓療法患者の抜柬に関する ガイドライン 2015 年改訂版, 第 1 版, 学術社, 東京, 2015, 12-15 頁.

2 ) 日本循環器学会 編; 心房細動治療 (薬物) ガイドライ ン 2013 年改訂版 http://www.j-circ.or.jp/guideline/. Accessed July 1, 2015, 13-14 頁.

3 ) Stangier J, Rathgen K, et al : The pharmacokinetics, pharmacodynamics and tolerability of dabigatran etexilate, a new oral direct thrombin inhibitor, in healthy male subjects. Br J Clin Pharmacol 64: 292303, 2007.

4 ）厚生労働省；血液凝固阻止剂「プラザキサカプセル」 服用患者での重篤な出血に関する注意喚起について. http://www.mhlw.go.jp/stf/houdou/2r985200000 1m1w3.html 2011.8.12

5 ）奥山裕司, 玉井佳子, 他監修：プラザキサ適正使用 のポイント. 第 2 版, 日本ベーリンガーインゲルハ イ公株式会社, 東京, 2014, 1-40 頁.

6 ）新美直哉, 各務秀明, 他：抗凝固療法施行患者の抜 柬における出血管理について一線状アテロコラーゲ ンの使用経験. 日口外誌 46: 445-447, 2000.
7 ) Connolly SJ, Ezekowitz MD, et al : RE-LY Steering Committee and Investigators. Dabigatran versus Warfarin in Patients with Atrial Fibrillation. N Engl J Med 361: 1139-1151, 2009.

8 ）永沢 光, 山口佳剛, 他：ダビガトランの投与によ り APTT が過剩延長した症例と出血性合併症を呈し た症例の特徴。脳卒中 34: 435-439, 2012.

9 ) Suzuki S, Otsuka T, et al : Dabigatran in clinical practice for atrial fibrillation with special reference to activated partial thromboplastin time. Circ J 76: 755-757, 2012.

10) Healey JS, Eikelboom J, et al : Periprocedural bleeding and thromboembolic events with dabigatran compared with warfarin: results from the Randomized Evaluation of Long-Term Anticoagulation Therapy (RE-LY) randomized trail. Circulation 126: 343-348, 2012.

11) van Diermen DE, van der Waal I, et al : Management recommendations for invasive dental treatment in patients using oral antithrombotic medication, including novel oral anticoagulants. Oral Surg Oral Med Oral Pathol Oral Radiol 116: 709-716, 2013.

12) Davis C, Robertson C, et al : Implications of Dabigatran, a direct thrombin, for oral surgery practice. $\mathrm{J}$ Can Dent Assoc 79: d74, 2013.

13) Breik $\mathrm{O}$, Cheng $\mathrm{A}$, et al : Protocol in managing oral surgical patients taking dabigatran. Aust Dent J 59: 296-301, 2014.

14) Romond KK, Miller CS, et al : Dental management considerations for a patient taking dabigatran etexilate: a case report. Oral Surg Oral Med Oral Pathol Oral Radiol 116: e191-195, 2013. 